\title{
PAstiche I
}

Reflections on nineteenth-century Australia

EDITED BY

Penny Russell and Richard White 


\section{Contents}

Individual papers in this collection retain original copyright. (c) Collection and introduction, Penny Russell and Richard White, 1994

This book is copyright under the Berne Convention.

All rights reserved. No reproduction without permission.

First published 1994

Allen \& Unwin Pty Ltd

9 Atchison Street, St Leonards, NSW 2065 Australia

\section{National Library of Australia}

Cataloguing-in-Publication entry:

Pastiche: reflections on nineteenth-century Australia.

ISBN 1863735356.

1. Australia-History-1788-1900. 2. Australia-Social

conditions-1788-1900. 3. Australia-Historiography.

I. Russell, Penelope Ann. II. White, Richard, 1951-

III. Title: Pastiche I.

994.02

Set in $10.5 / 12$ pt Goudy by Graphicraft Typesetters, Hong Kong Printed by SRM Production Services Sdn Bhd, Malaysia

$\begin{array}{llllllllll}10 & 9 & 8 & 7 & 6 & 5 & 4 & 3 & 2 & 1\end{array}$

\section{Acknowledgements}

Preface

Introduction: Australian history and the nineteenth century

1. Past silences: Aborigines and convicts in our historymaking Tom Griffiths

2. The white man's looking glass: Aboriginal-colonial gender relations at Port Jackson Ann McGrath

3. Aboriginal-European contact history: Problems and issues Henry Reynolds

4. Four patterns of convict protest Alan Atkinson

5. Towards independence: Recipes for self-government in colonial New South Wales Alan Atkinson

6. Egalitarianism John Hirst

7. The making of the Australian working class: An historiographical survey Stuart Macintyre

8. Uncovering poverty in Australian history C.T. Stannage

9. A boom for whom? Some developments in the Australian labour market, 1870-1891 Jenny Lee and Charles Fahey

10. Capital and labour: Responses to immigration in the nineteenth century Verity Burgmann 


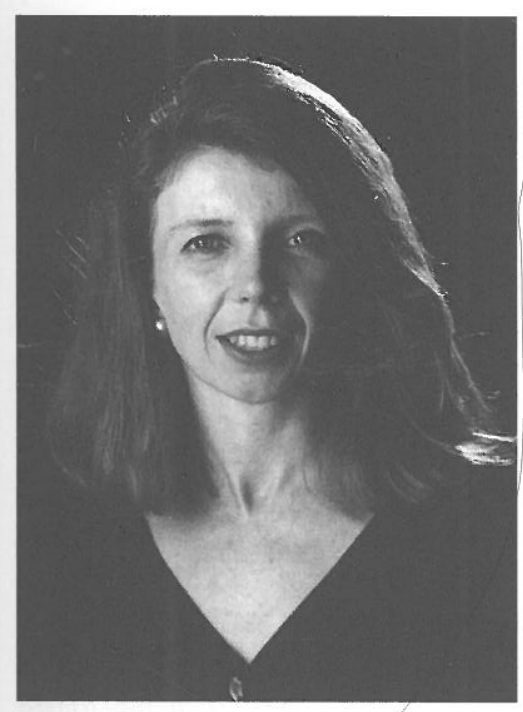

\section{AnN McGrath}

I had arrived in Sydney from Queensland via several years in Melbourne. Living at North Bondi amidst the Bicentennial hoo-ha, I found a subject that enabled me to contemplate my surrounds of rock, sea and harbour from a new angle. I first started working on Port Jackson materials as part of a new feminist history of Australia. Journals kept by members of the First Fleet led me into the intimate yet public thoughts of the earliest British intruders. They wrote as sexual beings, commenting poetically and openly on the attractions of the native women, at first hidden from their view. I was excited by the titillating evidence of past desire, surprised that past historians had turned a blind eye to it. It was easy to find the evidence, but interpreting this evidence of genteel courtship and aesthetic fantasies was another matter. Personally I was more familiar with the rather direct sexual overtures of post-hippydom. As a scholar I had studied the rough bravado of white stockmen in the Northern Territory. I also knew something of the differing reactions of Aboriginal women and men to white men's more recent sexual advances. But the Port Jackson Aborigines left few voices: it was all too long ago. This silence led me to concentrate more on documented white perspectives. Fortunately, cultural history has provided some fascinating studies of the sensibilities of eighteenthcentury gentlemen.

It might be reassuring if, as a historian, I were able to locate a specific point at which my broader interests in race and gender commenced, but I can't. Like most Australians, I have been pro- 
foundly affected by issues of gender and race, and have thought about them for as long as I can remember. But I do remember moments of heightened consciousness. Reading Germaine Greer's The Female Eunuch at fifteen was a revelation. It cheekily articulated sentiments that I could identify with, despite the fact that 'boys' remained the ever-exciting forbidden fruit during my segregated Catholic secondary years. Growing up in Queensland, I learnt that the subject of Aborigines was also forbidden, except as ghosts who had left some names in the landscape, or in their peremptory dismissal as 'bludgers'.

My history studies at the University of Queensland began with Asia, and it was not until I despaired of Japanese and Chinese language studies that my thoughts turned back to Australia. I became fascinated by the chasms in the historical record. Idealistically convinced that merely knowing the 'truth' about the past would be enough to expose the hypocrisy of the present, I believed that the study of gender and race could help redress injustice. Courses run by Ray Evans, Kay Saunders and Glen Lewis were especially inspiring. My desire to learn something more about Aboriginal history was helped by Ray Evans' suggestion that I consider researching the Northern Territory. After studying that frontier, Port Jackson presented a very different world. In stark contrast to the Territory, it was much-trammelled ground for historians, yet relatively little attention had been paid to Aboriginalwhite relations or gender issues. In this article I intended to show how gender fundamentally shaped the nature of these relations. The feedback I have had from readers is often a certain amazement, and a sense that there is something tragically curious about it all.

\section{Ann McGrath}

\section{The white man's} looking glass:

\section{Aboriginal-colonial gender relations at Port Jackson*}

Women have served all these centuries as looking-glasses possessing the magic and delicious power of reflecting the figure of man at twice its natural size. V. Woolf, A Room of One's Own.

N JANUARy 1788, Governor Arthur Phillip presented a looking glass to an unidentified Aboriginal man at Botany Bay. To the Aborigine, the gift-giver, covered in plumes as elaborate and bright as a bird's, offered a much stranger image than his own reflection. Half-cockatoo, perhaps, but was it woman or man? The Aborigine's trembling shock and confusion created a cross-cultural mirror for Lieutenant King, who realised that their clothed bodies must have appeared 'ridiculous'. ${ }^{1}$ British men suffered similar confusion when they first saw Aboriginal women. So unaccustomed were they to seeing naked female flesh in the open landscape that they likened them to the decorative statues in English gardens.

1 F.G. Fidlon and R.J. Ryan (eds), The Journal of Philip Gidley King, Sydney, 1980, pp. $33-5$ 
Gender relations between Aborigines and Europeans eventually grew out of these baffling moments. Reactions and reflections were not merely personal or private, but enmeshed in separate cultures of meaning. They were also encounters of power, politics and diplomacy. Imperialism created new sites for gender struggles and cultural confrontations. The interchanges which ensued between men of each group, between women, and across the sexes, were governed by two sets of gender configurations, each novel to the other. Within these, class and clan affiliations caused further dramatic diversity.

Aboriginal society's relatively egalitarian social structure, without kings or chiefs, and its internal emphasis on gender as a social, economic and political demarcation, increased the importance of gender in early colonial relations. Women spent much time together foodgathering and hunting, and partook separately in social and ritual arrangements. Women performed a crucial economic role by providing the staple food supply. They owned and had special responsibilities towards sites in the landscape, associated song cycles and dreaming stories. Their labour as reproducers and primary rearers of young children was vital, and they exclusively controlled ceremonies relating to reproduction. They also played an important role in 'love-magic', the business relating to pairing, and participated in male initiation ceremonies. Status and political power increased greatly with age. Nevertheless, despite considerable female autonomy, Aboriginal society was sexually asymmetrical, with the products of men's labours being more highly valued in both hunting and ritual spheres. Men's 'business' was considered more central to the well-being of the overall social group and, in negotiations relating to both sexes, men had the ultimate power which they could uphold through the threat of violence. ${ }^{2}$

Patriarchy was also fundamental to eighteenth-century British culture, and was a central organisational tenet of British colonialism. The travellers who 'discovered' and explored the 'new world' were men. Sexual adventures with local women were part of the male adventure of ocean travel and usually of establishing colonies. Indigenous women had long been seen as a fringe benefit of the men's maritime occupations, and other women of the south Pacific had a tradition of generous hospitality to visitors. In contrast to British women, all 'native' women were understood to be freely available. It followed that 'conquest' of Aboriginal women was an anticipated part of the colonisation of Terra Australis.

2 A. Hamilton, 'A complex strategical situation: gender and power in Aboriginal Australia', in N. Grieve and P. Grimshaw (eds), Australian Women: Feminist Perspectives, Melbourne, 1981, pp. 84 and passim.
Given that sexual exploitation was an important facet of British imperialism, ${ }^{3}$ why has the topic received so little attention with respect to the first British settlement in what was to become Australia? Part of the explanation stems from the perception of this period as 'convict' history, a category in which Aborigines go missing. An equally important conceptual barrier relates to gender, which is so rarely analysed as a central dynamic in the history of Australian colonialism. The few historians who have referred to British-Aboriginal sexual relations have blamed the documents as 'curiously silent' or 'mostly reticent'. This is only partly correct. ${ }^{4}$

Concerns about gender vitally motivated both sides. In the first official contacts in the Sydney region, it was no accident that males met males. Aboriginal men saw themselves as the appropriate people to confront intruders. In these initial encounters it is significant that the Aboriginal men's first vital enquiry related to gender. The British men's elaborate apparel disguised their masculine identity. This may have seemed merely amusing to Western observers, but gender specificity was crucial to Aboriginal diplomacy. It determined both their behaviour towards and their expectations of the strangers. As Aboriginal economic, social, political and ritual roles were divided according to gender, and the most serious kin avoidance rules applied to the opposite sex, ${ }^{5}$ association with newcomers of unknown kinship classification and obscure sexuality would be awkward if not impossible. Aborigines could not initially discover the kin status of the British arrivals, but they could enquire about their sex.

After gifts had been distributed at a meeting between Lieutenant Philip Gidley King's party and local men on 20 January 1788, the Aborigines pointed to their own penises, thus indicating by gesture that they wanted to know the strangers' sex. King did not voluntee to exhibit himself, but explained, 'As they took us for women, not having our beard grown, I ordered one of the people to undeceive them in this particular when they made a great shout'-one which King took to be admiration! ${ }^{6}$

3 See R. Hyam, 'Empire and Sexual Opportunity', Journal of Imperial and Com monwealth History', vol. 14, no. 2, 1986.

4 W.E.H. Stanner, 'The History of Indifference thus Begins', Aboriginal History, vol. 1, no. 1, 1977, p. 15; G. Williams and A. Frost, 'New South Wales: expec tations and reality', in Williams and Frost (eds), Terra Australis to Australia, Melbourne, 1988, p. 195.

5 See D. Bell, Daughters of the Dreaming, Melbourne, 1983; F. Gale (ed.), Woman's Role in Aboriginal Society, Canberra, 1978; A.P. Elkin, The Australian Aborigines, (revised) Sydney, 1974, pp. 147-54.

6 Fidlon and Ryan (eds), Philip Gidley King, pp. 34-5. 
Captain Watkin Tench of the marines describes another incident at Botany Bay where Aborigines wanted to examine the light coloured bodies hidden by clothing and a young boy was volunteered for the task. Tugging at his clothes, they expressed puzzlement regarding gender, and when shown, 'burst into the most immoderate fits of laughter', talking vociferously and excitedly before they ordered Tench's party to leave. The joke probably stemmed from the white men's 'unmanly' appearance and behaviour. G.B. Worgan, surgeon of the Sirius, explained the 'very singular Curiosity' among the men regarding their sex. When the Aboriginal man tore open their shirt buttons, they were amazed at not seeing women's bosoms. As Worgan's party could not explain masculinity verbally, 'We had Recourse to the Evidence of Ocular Demonstration, which made them laugh, jump and Skip in an Extravagant Manner'?

King's anonymous flasher evoked a differing political reaction, probably from another clan. The Aboriginal men signalled a group of women on a nearby shore. Aboriginal sign-language indicated 'their persons were at our service'. King claimed to decline this hospitality, yet picked out a particular woman. She put her child down, and allowed him to personally affix a handkerchief "where Eve did the Fig leaf'. Aborigines waiting on the shore shouted; another ran into the bushes, making a grass leaf belt, and danced out comically.

In the first days at Botany Bay and Port Jackson, the officers approached Aboriginal men on several occasions asking to see their women. Phillip, King, Hunter, Tench and Southwell all describe instances where their parties persevered with demands and ploys, cajoling and entreating the Aboriginal women to come forward, and when they did, to come within their grasp-ostensibly so they could decorate their naked bodies with gifts. It was sometimes implied that Aboriginal women should come forward as a sign of trust, but no similar gesture was forthcoming from the British. The officers assumed Aboriginal men to be the power-brokers so there was no need to justify a meeting with women on diplomatic grounds. Their impatience to see the Aboriginal women involved unashamed sexual curiosity; in their journals and letters there was no need to state the obvious.

But the British found Aboriginal policy on sexual matters ambiguous. In many parts of Aboriginal Australia, a male-negotiated offer of

7 Watkin Tench, 'A Narrative of the Expedition to Botany Bay', 1789, in L.F. Fitzhardinge (ed.), Sydney's First Four Years, Sydney, 1961, p. 36; G.B. Worgan, Journal of a First Fleet Surgeon, Sydney, 1978, p. 6. women to outsiders was a sign of peace and hospitality. ${ }^{8}$ Sometimes longer-term arrangements served to obligate the newcomers into specific reciprocal duties. In the first decade of British intrusion in the Sydney region, each clan made its own strategic decision concerning behaviour towards strangers. In some early encounters, Dharuk men appeared to freely offer the womenfolk, and British officials had declined. In several subsequent meetings, the Aboriginal men alone communicated with the white men, and the women were not sighted. It was reported that the men kept them out of reach, ${ }^{9}$ as though suspicious of their intentions. Aboriginal protocol demanded that the men deal with all male delegations, and with such a well-armed party this would be strictly enforced. The women were reportedly hiding. Possibly they feared the newcomers as spirits, or the large assembly as some kind of dangerous men's business. The women may have wanted to protect themselves and their children from kidnapping. On the other hand, Aboriginal women often pursued their own activities so in some instances may have simply been elsewhere.

Individual Aboriginal women's behaviour varied, and their own active role in sexual interaction should not be underplayed. In May 1788 , George Worgan explained: 'if they ever deign to come near You to take a Present, they appear as coy, shy and timorous, as a Maid on her Wedding Night... but when they are, as they think, out of your reach, they hollow [sic] and chatter to You, Frisk, Flirt and play a hundred wanton Pranks, equally as significant as the Solicitations of a Covent Garden Strumpet'. ${ }^{10}$ Tench found that the question of the women's sexual availability was more perplexing than anything else about Aboriginal society. 'There is no part of the behaviour of these people, that has puzzled us more, than that which relates to their women'. Sometimes the women were held back 'with every symptom of jealous sensibility: and sometimes offered with every appearance of courteous familiarity'. ${ }^{11}$ Considering their other South Seas experiences, this must have been both confusing and disappointing.

8 See A. McGrath, 'Born in the Cattle': Aborigines in Cattle Country, Sydney, 1987, pp. 74-5, R.M. Berndt, The World of the First Australians, Sydney, 1977, pp. 189-90, A.P. Elkin, The Australian Aborigines, Sydney, 1938, pp. 161-2.

9 Southwell Papers, HRNSW, vol. 2, p. 701. See also HRNSW, vol. 2, pp. 6889, vol. 1, pp. 130-1; William Bradley, A Voyage to New South Wales, Sydney, 1969 , pp. $70-71,66-8,89,99$.

10 Worgan, Journal, p. 146

11 Tench, 'Narrative', p. 49. Southwell referred to the men's jealousy or guard over women as their 'grand foible', p. 702; Bradley also refers to Aboriginal men's jealousy, Voyage, p. 141 
Aboriginal men's thoughts are harder to read; logically they could have been waiting for the pale strangers to share their own women. Like the unwillingness of the English to accept the Aboriginal women first offered, their refusal to offer white women may have been taken as hostility. Puzzled by the lack of a unified Aboriginal stance, the British feared the women might be used as decoys to lure them to their deaths. Perhaps Aborigines did exploit the obsessive interest of these lonely men. Phillip subsequently warned the marines to be wary of causing trouble over sexual matters in the first couple of months. In late March 1788, Worgan lamented that women would not permit them to come near. ${ }^{12}$ A few months later, Tench stated that they feared 'alarming the feelings of the men on so tender a point' so they treated the women with 'distance and reserve' to remove impressions of their intending 'aught'. ${ }^{13}$

In the early years, British sexual policy towards Aboriginal women was largely ad hoc. Preconceptions had to be modified by the conditions existing in the colony. These included the willingness and attractiveness of the local Aboriginal women and the degree of control over the non-Aboriginal population. Phillip had originally wanted the garrison to be supplied with suitable women, preferably from the 'Friendly' (Tahitian) islands. In order to establish a peaceful relationship with the Aborigines, he planned to prevent the transports' crews from fraternising with them. Contact with convicts would be banned, for they might steal and use their weapons, abuse the women and thereby 'disgust' the Aborigines, causing bloodshed. While he reasoned that after a time the Aborigines would probably 'permit' their women to live with and marry the British arrivals, he feared that relations could be ruined by cruelty and violence. Consequently he planned to punish offenders with exile and hard labour. ${ }^{14}$

Exactly when sexual relations between British men and Dharuk women became frequent is unclear. By late 1790, groups of Aborigines, including Bennelong and his relations, often stayed around the Sydney Cove settlement. Lieutenant David Collins implied that Aborigines suffered from venereal disease by 1791, confiding 'I fear our people have to answer for that'. ${ }^{15}$ By 1796 , prostitution of Aboriginal

12 Worgan, Journal, pp. 47-8.

13 Tench, 'Narrative', p. 49.

14 'Phillip's Views on the Conduct of the Expedition and the Treatment of the Convicts 1787', HRNSW, vol. 1, part 2, pp. 52-3.

15 D. Collins (ed. Brian Fletcher), An Account of the English Colony in New South Wales, Sydney, 1975, facsimile edn, pp. 464, 495-6. women had become commonplace. White women were at a premium, and Aboriginal people now needed to acquire food and other goods. Some of the Aboriginal girls who lived in the settlement 'spent the night' on board the ships in exchange for bread, blankets and shirts. Collins was disturbed by the women's lack of chastity, claiming that at least they had 'learnt shame enough' to conceal the spoils of their stay. ${ }^{16}$ Rather, they were probably hiding their loot so they could get it to their most appropriate family members.

Some women may have been trying to incorporate the newcomers into their society, hoping this could bring greater respect for their laws relating to land, resources and kin reciprocity. Some relationships were ongoing, and the couple lived together. Although insufficient is known about the first decade of settlement, by 1800 many Aborigines lived with settlers on the Hawkesbury. This allowed them to continue to use traditional land for food resources, as well as carry out this sexual form of exchange, while others performed general handywork and hoed fields. Several murders of Hawkesbury settlers were apparently in retaliation for sexual offences: for abduction of women, ill-treatment, or when whites failed to fulfil obligations resulting from their sexual relationships. Fear of Aboriginal violence prompted some farmers to leave, seriously threatening the colony's food supply. Governors often blamed the close liaisons: in 1802 King gave orders forbidding white residents from 'harbouring' Aborigines. Likewise, Macquarie found in 1814 that murders of a soldier and three others had occurred because 'idle and ill-disposed Europeans had taken Liberties with their Women'. ${ }^{17}$ Such conflicts were usually blamed on the convict classes.

The male ruling-class believed that they knew how to conduct themselves with women. Eighteenth-century Britain was an era typified by the free expression of male heterosexuality. The enlightenment belief that nature was good made desires also good. Men were made to follow pleasure, and it was thus 'natural' to follow their sexual urges. Such passions were considered constructive, beauty being associated with benevolence. ${ }^{18}$ The pleasures of the mind and body were thought to be mutually enhancing. The science of hydraulic physiology gave

16 ibid., p. 464.

17 Hunter to Duke of Portland, January 1800, HRNSW, vol. 4, pp. 1-3; Hobart to King, HRNSW, vol. 4, p. 684. See Macquarie, May 1814, HRA, vol. 8, pp. 250-1. Caley's Account of the Colony, 1803, HRNSW, vol. 5, p. 299.

18 R. Porter, 'Mixed Feelings; the Enlightenment and Sexuality in Eighteenth Century Britain', in P.G. Bouce, Sexuality in Eighteenth Century Britain, Manchester 1982, pp. 2-3. 
credibility to the idea that regular (male) 'sexual discharges' were healthy. ${ }^{19}$ New freedoms only applied to males and women were portrayed as men's playthings. ${ }^{20}$ Nonetheless, men preferred an amorous woman to a cold one.

For educated men, sex with sensibility thus seemed to solve the English enlightenment problem of how men could 'indulge their own selfish passions without danger to the social order. ${ }^{21}$ One way was to associate with women outside the class system: indigenous women were thus the perfect target for 'sowing wild oats', and they had been made especially attractive by the ideal of the noble savage. Their place in the eroticism of the wealthier classes was signified by the wellknown London brothel keeper who dressed up as a Tahitian Queen to lead the regular 'feast of Venus' in which twelve beautiful 'spotless virgins' in her employ performed a pseudo-Polynesian dance. ${ }^{22}$

Physiognomy, or the judgement of inner character and disposition from the features of a person's face or form of the body, was popular in the early eighteenth century, but it had been temporarily suffocated by such artistry of make-up, wigs and masks. 'Make-up' was seen as part of a sexual game, hence the contemporary slang 'making faces' for having sex. ${ }^{23}$ The later Georgians, however, became dissatisfied with artifice, which could hide the false heart, so a revival of physiognomy occurred. Its new advocates argued that beauty could be recognised below the superficial mask, in structures of the face and features which could not be disguised. This was crucial in the company of elite women as touching taboos confined private romancing to words and looks. The look thus had to 'speak true'. Other body language could also serve as a language of the heart, short-circuiting hypocrisy. Involuntary impulses of the 'nerves' such as tremblings, palpitations, weeping, quivering and swooning were consequently thought of as reliable measures of uncontrived feeling. ${ }^{24}$

Port Jackson authors certainly relished details of courtship stages, prolonged rituals of flirtation, cat and mouse games, playful decoration and ornamentation of the opposite sex. They savoured the tantalising combination of nudity and timidity. It seems some wanted to imagine Aboriginal women to be sexual innocence personified: the antithesis

19 ibid., p. 5 .

20 ibid., p. 15

21 ibid., pp. $5,9,20$

22 ibid., p. 9.

23 Roy Porter, 'Physiognomy and Fashion', Etudes Anglaises, 38 Annee, no. 4, October-December 1985 , p. 389.

24 ibid., p. 393. of convict women as they perceived them, with the 'God's police' stereotype absent from the equation. Lieutenant William Bradley described in detail the first interview with Aboriginal women on 29 January at Port Jackson. When a party landed at the upper part of the north arm, a man and a female elder met them but as they approached a larger group, the women ran away. Bradley and companions used 'many entreaties' unsuccessfully. The next ploy of Bradley's party was to insist that the women collect presents; they tried to retreat, but the old man insisted that they come forward. Bradley explains of one: 'We ornamented this naked beauty with strings of beads and buttons around her neck, arms and wrists. She appeared rather frightened, although she affected a laugh and seemed pleased with her presents'. Other women then approached the side of the boat, protected by the men's spears. They were also ornamented; some were fearful, trembling and laughing. Bradley approved them as 'straight limbed and well featured, their voices a pleasing softness'. ${ }^{25}$

Despite being put off by their snotty noses, George Worgan still waxed lyrically about Aboriginal women's beauty. They had a 'Proportion, a Softness, a roundness and plumpness in their limbs and bodies that would excite tender and amorous Sensations, even in the frigid Breast of a Philosopher'. ${ }^{26}$ When surgeon John White's party approached a group of Aborigines in August 1788, every 'gentleman' chose a female, and presented her and family with trinkets. White wooed his choice by decorating her head, neck and arm with ribbons torn from pocket handkerchiefs, at which she exhibited 'coquettish airs'. When she admired his coat buttons, he unhesitatingly cut them away, and tied them around her waist with a string. He was titillated by her turning from him with a 'look of inexpressible archness' or mischievous sauciness. However, he was disgusted by the brash behaviour of an old woman who adopted 'most indecent attitudes' in order to solicit a present. ${ }^{27}$

Captain Watkin Tench of the marines was also attracted to Aboriginal women, preferring those without traditional nasal decorations, scarification and paint-work. ${ }^{28}$ Initially he mentioned their 'pleasingly soft and feminine' voices, confiding suggestively 'Of the other charms

25 Cited in J. Cobley, Sydney Cove 1788, London, 1962, pp. 43-6.

26 Worgan, Journal, pp. 47-8. The uncontrolled nasal excreta he describes is evidence of the introduction of the common cold, which caused many deaths among Aborigines.

27 A.H. Chisholm (ed.), Journal of a Voyage to New South Wales by John White, Sydney, 1962, p. 159

28 Tench, 'Narrative', pp. 47,276. 
of the ladies I shall be silent.... Then he sought their essence as women: 'they shew a degree of timidity and bashfulness, which are, perhaps, inseparable from the female character in its rudest state'. Tench was openly infatuated by the eighteen-year-old Gooreederana, a young Cameragal women who 'excelled in beauty ... the firmness, the symmetry, and the luxuriancy of her bosom, might have tempted painting to copy its charms: her mouth was small; and her teeth ... were white, sound, and broken...29 Gooreederana's natural beauty 'inspired art to copy her charms'. Tench loved Aboriginal women's 'long thick sweepy' eyelashes. ${ }^{30}$

Tench was also much taken by Barangaroo, (also known as Daringa), the kidnapped Bennelong's past wife, and at this time with Colby. Thomas Watling's portrait depicts her as a beautiful young woman with a confident gaze, full lips and attractive breasts. ${ }^{31}$ Watkin Tench met her on the north shore in September 1790. Before she came forward, Abaroo, who was with Tench's party, gave her a petticoat to wear. Tench responded that 'this was the prudery of the wilderness, which her husband joined us to ridicule, and we soon laughed her out of it'. She dropped the garment, standing naked. Tench explained that they then combed and cut her hair, and offered her wine, which she refused. Tench was impressed by her 'gentleness and timidity'. Nine months later, Tench claimed she was aggressive and a vixen, but for the moment she inspired romantic fantasies-he was amazed that 'amidst a horde of roaming savages, in the desert wastes of New South Wales, might be found as much feminine innocence, softness and modesty ... as the most finished system could bestow, or the most polished circle produce'. ${ }^{32}$ Transcending class, she was a 'natural aristocrat'.

Nonetheless, female nudity as a norm must have been mind-boggling for these eighteenth-century Englishmen. In coy language, midshipman Daniel Southwell described Aboriginal women as dressed in the 'garb of native innocence, which as its veil it seemed had reference only to the intellectual organs of vision. ${ }^{33}$ Nakedness did not mean brazenness: of Barangaroo, Barrington thus wrote 'there is such an air

29 ibid., p. 276.

30 ibid., p. 275.

31 See Plate 18 and references in B. Smith and A. Wheeler (eds), The Art of the First Fleet, Melbourne, 1988

32 Tench, 'Narrative', p. 184.

33 Daniel Southwell to Mrs. Southwell, 12 July 1788, in HRNSW, vol. 2, p. 689. of innocence about her that clothing scarce seems necessary, ${ }^{34}$ 'Innocence' was not associated only with youth, and it is unlikely that anyone thought a married woman sexually inexperienced. 'Innocence' seemed to mean passivity or unselfconsciousness, yet by the way Barangaroo charmed both Aboriginal and white men, she was an expert at the art of sexual attraction.

Some Europeans keenly observed changes in a woman's posture and confidence when ritual paint was worn. When Barangaroo returned to town in special ochres on her face and back, she was observed to walk with special pride in this 'make-up.". ${ }^{35}$ Southwell was excited to observe embarrassment shown by Aboriginal women, but painted or not, he was unable to discern the blush, which was considered proof of modesty. He thus lamented that their complexions would not display 'that captivating suffusion which on similar occasions adds such graces and so enhances the charms and many attractions of the fair in our far-happier climes. ${ }^{36}$ George Barrington differed, claiming with approval that the 'blush of shame' had in fact been observed 'on the dark cheeks of a female of New South Wales'. ${ }^{37}$

Aboriginal women were expected to understand the non-verbal language of European chivalry. The use of the handkerchief was well established in courtly manners as a romantic invitation. On one occasion Worgan sighted a group of women in about six canoes. He bellowed out to them, and they called back. Excitedly, Worgan tied his silk handkerchief to a piece of wood and threw it into the water. He watched closely for signs of encouragement: one woman indeed paddled after it, but held and looked at it disdainfully, then 'with utmost Indifference' tossed it into the dirtiest corner of the canoe. So on the 24th March, Worgan confided to himself: 'If that is the Way you treat my Favours Madam . . . I'll keep my Handkerchiefs ....38 In the journal bearing George Barrington's name, published in 1795, courtship took on a semblance of anthropological authenticity, with the hero recognising the importance of patience and obliging himself to his sweetheart's kin through gift-giving. His plan was to 'cement the friendship' between her extended family who he hoped would stay with him at Parramatta, and to 'promote certain views just dawning

34 G. Barrington, The History of New South Wales, London, 1810, p. 94; Worgan, Journal, p. 47.

35 Barrington, History, pp. 2-3; see also preface.

36 ibid.

37 ibid., pp. 2-3.

38 Worgan, Journal, p. 47. 
on my mind with respect to Yeeariana'. He lavishly described this young woman as a fine specimen of Greek statuary, but with shining black eyes. ${ }^{39}$

The botanist Joseph Banks was possibly the first to use Garden of Eden references in response to the nakedness of Aboriginal women. ${ }^{40}$ It was an obvious Christian reference, popular at a time when Milton's epic Paradise Lost was extremely influential. Repeated Edenic allusions by the journal writers of Port Jackson show its symbolic power. Aborigines could thus be equated with origins, beginnings, living artefacts of the ancient, of primordial times, in an innocent paradise. Not surprisingly, our observers found Eve's nakedness of much more interest than Adam's. And in being depicted as a kind of Eve, Aboriginal woman was seen as a temptress who could lead men to follow dangerous passions.

Yet she did not even wear the obligatory fig-leaf. Lieutenant King resorted to a telling mixture of Latin and French to describe the women's nudity: 'they were puris naturalibus, pas même la feuille de figeur'. ${ }^{41}$ The Latin was the language of science, often used by men when discussing the erotic to exclude female ears from conversations, and French was the language of love. The phrase conflates the apparent conflict of values where indigenous women were seen as scientific novelties, as subjects of romance, and objects of Christian moralising. King probably justified his erotic voyeurism in tying a handkerchief around an attractive woman's hips as an initial lesson in 'civilisation'. Sin had arrived in the Garden of Eden; Christians leering at the bodies of exotic Eves had to teach Aborigines shame at nakedness.

The pagan goddess Venus was another image deployed by writers and artists. ${ }^{42}$ The sexual act was sometimes referred to by British writers as the 'rites of Venus'. Venus was 'venereal' but her significance not that of pure biology or science. She symbolised eroticism. Venus, the bashful goddess, conveyed much about the ruling aesthetic and moral values. Her most common eighteenth-century form was the Venus de Medici, the sea-born Venus, which reflected themercantilist interests of the era, with trade routes now crossing the seas. Her statue was usually half-secluded in gardens by a pool or grotto, but Venus looked

39 Barrington, History, pp. 136, 138.

40 J.C. Beaglehole (ed.), The Endeavour Journal of Joseph Banks, vol. 2, Sydney, 1962, pp. 54, 124

41 Fidlon and Ryan (eds), Philip Gidley King, p. 35.

42 See 'Femme du Cap de Diemen by Copia after Piron' in B. Smith, European Vision and the South Pacific, London, 1960 around 'inviting you with her into the recess'. The image fitted the tastes of the landed gentry: a form fully available to the owner, but excluding others, 'a kept mistress rather than a common whore'. Her gestures combined 'concealment and display, modesty and availability'. ${ }^{43}$ In constructing Aboriginal woman as Venus, European men symbolically made her a still-life rather than a living human.

Aboriginal men's conceptualisation of female beauty interested male observers like Tench, who wrote: 'Were a New Hollander to pourtray [sic] his mistress, he would draw her the Venus aux belles fesses'. This time French is used to describe the beautiful buttocks of the wellknown Venus Callipygos of Hellenistic art. ${ }^{44} \mathrm{He}$ also refers to another 'particular' as 'eminently luxuriant', and I am surprised that his excellent French vocabulary let him down! Writers thus 'drew' Aboriginal women, even in the eyes of their men, to emulate widely-based European aesthetic traditions. The Christian Eve and pagan Venus had much in common; both concealed their genitals, this coyness making women far more titillating. ${ }^{45}$

We have little evidence about Aboriginal men's attitudes towards European women, though what we have indicates sexual interest. Tench describes a group of Aboriginal men at Port Jackson when they saw white women for the first time. After an unsuccessful attempt to 'divert their attention', Tench's preconceptions of 'natives' (or of men in general) led him to expect that they would molest the women. Rather, they watched from several paces away, 'expressing very significantly the manner they were attracted' ${ }^{46}$ In May 1788 , some Aboriginal men expressed great interest when they sighted a woman aboard a ship. They responded so uproariously it was thought their lungs should burst. ${ }^{47}$

Only a few Aboriginal men had access to the apparel of British gentility. The Wangal man Bennelong, captured by Governor Phillip in late 1789 to force communications between the British and the Aboriginal population, had quickly recognised the importance of dress for Englishmen, especially its role in attracting women. He understood how clothing was seen to enhance rather than disguise sexuality and

43 J.G. Turner, 'The Sexual Politics of Landscape: Images of Venus in EighteenthCentury English Poetry and Landscape Gardening', in H.C. Payne (ed.) Studies in Eighteenth Century Culture, vol. 1., London, 1982, p. 343.

44 Tench, 'Narrative', p. 277 and ref. 330.

45 Turner, 'Sexual Politics', pp. 358-9.

46 Tench, 'Narrative', p. 51.

47 Collins, An Account of the English Colony, p. 367. See HRNSW, vols 4 and 5; Caley's Account of the Colony, HRNSW, 1803, vol. 5, p. 299. 
was an important badge of status. His exceptionally polished table manners when white women were present ${ }^{48}$ and his infatuation with certain female visitors amused the white men.

English estimates of Aboriginal masculinity varied. Along with the romantic 'noble savage' depictions, Cook and Banks had left impressions that the men were cowardly, unfriendly and vindictive. Phillip's respect for Aboriginal men grew upon acquaintance, at least in the initial year. 'They do not ... want personal courage; they very readily place a confidence, and are, I believe, strictly honest among themselves'. ${ }^{49}$ The upright postures, dignity and 'undaunted behaviour' of Aborigines on the north shore inspired the name 'Manly' ${ }^{50}$ Men's role in hunting larger game may have also earnt them respect, as hunting was the favourite sport of the British gentry. British journal-writers were also fascinated by tooth evulsion rituals, and understood the associated masculine prestige after trial by ordeal. ${ }^{51}$ Aboriginal revenge killings of convicts who stole canoes and equipment were also considered worthy male behaviour.

Aboriginal men's treatment of their own women received condemnation, epitomised by frequent reports of brutal marriage customs. Marriage by capture especially attracted the writers' attention, and embellished versions of virtually identical stories are repeated in various journals. Such marriage consisted of a man raiding another group for a wife, stupefying her by blows and beatings, and then taking her for his own. ${ }^{52}$ This was the antithesis of courtship, and sharply contradicted the noble savage idyll, especially since male behaviour towards women was used by the British as an important yardstick of another society's worth. Paradoxically, the Aborigines providing this evidence were themselves victims of kidnapping by Governor Phillip's men, and state and private violence were outstanding features of convict society, with pack-rape of women commonplace. ${ }^{53}$ Yet writers did not compare

48 Collins, An Account of the English Colony, p. 367

49 Phillip to Marquis of Lansdowne, 3 July 1788, in HRNSW, vol. 2, p. 411

50 Tench, 'Narrative', p. 141.

51 J. Urry 'Savage Sportsmen', in I. and T. Donaldson (eds), Seeing the First Australians, Sydney 1985. Collins, An Account of the English Colony, p. 483.

52 For example, see Tench, 'Narrative', pp. 160, 289, 290, 202; J. Cobley, Sydney Cove, 1789-90, Sydney, 1963, p. 319; Barrington, History, pp. 35-6. For fuller discussion see B. Malinowski, The Family Among the Australian Aborigines, New York, 1963 [1913] pp. 39-42, 53-4.

53 Collins, op. cit., p. 363. Recent authors have tended to skirt this difficult subject. For example, see P. Turbet, The Aborigines of the Sydney District before 1788, Sydney, 1988 and R.J. Lampert, 'Aboriginal life around Port Jackson, 1788-92', in Smith and Wheeler (eds), Art of the First Fleet, p. 34
Aboriginal customs with those of convicts or their gaolers, but with standards of the noble. Refined men were supposed to be gentle to women, 'gentlemen'. Women were not supposed to do heavy work, especially outside the home, and hence Aboriginal women were classed as chattels because of their work fishing and carrying. Their earlier shyness and avoidance of white men, which followed avoidance protocol applicable to both sexes, were misunderstood as proof that they were under 'great subjection' by their men. ${ }^{54}$

Yet British men's attitudes towards anti-female violence were ambivalent. Bennelong's assault of the young woman Boladeree in November 1790 attracted comment ${ }^{55}$ and when Bennelong made his intention to kill her well-known, Phillip ordered sentinels to protect her. (This revenge against her and her father was condoned by Barangaroo and Boladeree's husband and was part of customary law.) Although Tench shared Phillip's concern that women not be beaten, he nonetheless admired Bennelong's 'intrepid disregard for personal risque [sic]. ${ }^{56}$ Tench also condoned 'deserved' violence: although he was horrified that the 'gentle Daringa', Colby's wife, had head scars, Barangaroo was a 'scold, a vixen, and nobody pitied her'. He claimed that the Aboriginal women 'often artfully study to irritate and inflame the passions of the men'. ${ }^{57}$

Examples of violence by women against their husbands are mentioned in the journals, but they are not accorded the same attention. Barangaroo was very assertive and insisted on Bennelong's obedience in many instances. He usually complied, but the diary writers do not dwell upon male obedience to women. Rather, they were disappointed because such behaviour did not conform to their ideal femininity. Appraisals of Barangaroo thus changed dramatically when she broke Bennelong's tools and paddles and successfully prevented him going to strange country (Parramatta) with Phillip. ${ }^{58}$ The English, while reluctant to interfere between husband and wife, seemed to think Bennelong somehow 'emasculated' by her power. After all, their women had not stopped them travelling where they wanted. Despite Bennelong's influential bragging about the advantages of violent treatment for keeping women in their place, it seems the older Barangaroo often had the upper hand. Yet for the British, Aboriginal

54 Phillip to Lord Sydney, 15 May 1788, HRNSW, vol. 1 part 2, p. 130; Tench, 'Narrative', p. 291; Collins, An Account of the English Colony, pp. 485-6, 499. 55 For example Tench, 'Narrative', p. 202.

56 ibid., pp. 200-3.

57 ibid., p. 291.

58 ibid., p. 390. 
women were either submissive, or nagging and difficult; they did not class their exercise of authority or choice as a sign of status.

Nor did Aboriginal women necessarily hold the gallant behaviour of European gentlemen in high esteem. While Bennelong may have adapted 'so readily and successfully' to the expectations of British manhood, it was a lonely life. When he returned from England in 1795 after a three-year absence, his wife had taken up with another man. He became so frustrated by his celibacy that he abducted Booreea, Colby's wife. On various occasions, he tried to corner his ex-wife, Barangaroo, but she defended herself, and her new husband and other kin also protected her, leaving him with two broken teeth and a permanently divided upper lip. Colby had sarcastically asked if Bennelong's behaviour was a 'specimen of English manners', ${ }^{59}$

The British writers' overall emphasis on Aboriginal women's subjection should be understood partly as a signal of their male desires. They wanted to reinforce their sense of superiority over their competitors for land and women, so it was necessary to prove Aboriginal men less appropriate suitors than themselves. To claim that Aboriginal men did not court their women at all was the ultimate proof of a superior right to the land's beauties. When some Aboriginal women took advantage of the British to escape domestic troubles, ${ }^{60}$ this confirmed the white men's preconceptions of their intolerable situation. However, when Aboriginal women brought up amidst white people chose to leave and return to their own society, the British dismissed this as revealing a primitive inability to be 'civilised'.

Stereotyped views of 'savage' masculine behaviour served another important function as they scared off most English women. ${ }^{61}$ Any white woman who dared associate with black men could anticipate severe ostracism from her own society. Convict women who escaped and were thought to be living with Aborigines, unlike the men who joined Aborigines, were considered to have been 'debased'. ${ }^{62}$ Any English woman who voluntarily became involved with a black man was cruelly treated, as demonstrated by a later case in April 1804. A complaint was made to a local magistrate, whereby the black man was sacked from his job. 'Madam Desdemona was turned adrift with contempt and detestation; for if any aggravation be conceivable to an offence obnoxious to morality as to the laws divine and human, it was reserved

59 Collins, An Account of the English Colony, p. 390.

60 I. McBryde, Guests of the Governor: Aboriginal Residents of the First Govern ment House, Sydney, 1989, p. 17

61 J. Cobley, Sydney Cove 1788, 14 November 1788, p. 249

62 Collins, An Account of the English Colony, p. 406. for this offender, whose paramour, to perpetuate her infamy, was of a complexion diametrically contrasted to her own'. ${ }^{63}$ This case reflects the double standard favouring the sexual and 'racial' freedoms of white men, and it also reveals the need to uphold patriarchal power within the colonial society. White men, as the colonising group, had to be seen to be in control of white women.

In their every action, white men, claiming to spread 'civilisation', were disseminating (to use a phallocentric term) particular patriarchal gender roles and expectations. Interracial sexual relations endangered colonial power relations, potentially threatening authority by opening the way for collusion with Aborigines. The British had difficulty establishing a negotiating basis with a non-hierarchical society, and Aborigines had difficulty incorporating whites into their kinship structures, or maintaining control of the bargaining situation. Sexual relations between the two groups were never balanced. Whereas Aboriginal women were considered attractive to white men, who had the trade power to gain their favours, Aboriginal men, genteel or otherwise, could be a failure in both worlds. They had lost their land, and Aboriginal women had more freedom to reject them, especially if absent from their country. Both Aboriginal women and men wanted sexual partners from their own people. Even if captured and ties severed, they returned bush. Aboriginal attitudes to sexuality and gender relations thus came to be seen by Europeans as the main stumbling block to Aborigines acquiring civilisation.

In order to love Aboriginal women, the British writers had to accommodate them into their cultural categories. Judging at a distance, they came up with the titillating colours of Eve and Venus. This was perhaps the delicious 'courtship phase', the appetiser of the imagination. In the context of Terra Australis, Eve and Venus merged in the colonial form of the garden of Eden. To European eyes, it may not have been a paradise, but it was a 'virgin' landscape yet untampered with by 'civilised' 'man' and hence the 'nether Eden' yet untampered Through incorporating Aboriginal women into their artistic tradition, they could assert ownership over them. The women would be first, the land next. Although the land may have been declared British, only little had been taken from the Aborigines, and the landscape had not yet been interpreted for the British psyche. On the other hand, women were often used to symbolise the land, especially in relation to

63 Sydney Gazette, 21 April 1805. The indexers list this as a case between an Aboriginal and a female convict, but this author does not exclude the pos sibility that a black convict could have been involved. 


\section{PASTICHE I}

conquest, and Aboriginal women were an appropriate choice given the hegemony which the colonisers sought to establish.

The offspring of some unions between white men and Aboriginal women may have been a short-lived harmony, but once Aboriginal women entered into more open relations with lower-class Europeans such as sailors and convicts, they were spoken of as unchaste and common prostitutes, lumped in with the other 'damned whores'. For Aboriginal women, sexual relations with all classes of British men brought sexual and other diseases, causing infertility and later depopulation. For Aboriginal men, essential elements of their authority were rapidly eroded.

The early British visitors could only worry about the dangers such femme fatales might bring to them: those foretold by the ancient precedents of the temptress Eve, and the melodious singing of the half-bird sirens of the sea. While British men did not have to strip the bodies of Aboriginal women, it was necessary to 'unveil' the mysterious musical qualities of their womanhood. The British 'discovery' of Aboriginal women entailed the dual revelation of an exotic and unknown culture and a new type of woman, or 'other'. Sexual desire sharpened interest in this new genre of female existence, which if not explored, charted and mapped must at least be drawn in words, and sculpted within a male-imagined world. Like the Venus statue, the form of Aboriginal woman might then be positioned near a pool in which today's eyes might also see, as in a looking glass, the pale but revealing exposure of that past onlooker: genteel British manhood.

\section{Bibliographical note}

On the earliest Aboriginal contacts with the British at Port Jackson, it is hard to go past the first fleet journals by Tench, Collins, Hunter, Bradley and Worgan, which are highly readable and all available in fascimile editions. W.E.H. Stanner's 'The History of Indifference Thus Begins', Aboriginal History, 1977, no. 1, analyses first encounters between Aborigines and whites at Botany Bay and Port Jackson. Also useful are R. Lampert's 'Aboriginal life around Port Jackson, 1788-92' in B. Smith and A. Wheeler (eds), The Art of the First Fleet, Melbourne, 1988 and G. Williams and A. Frost 'New South Wales: expectations and reality', in Williams and Frost (eds), Terra Australis to Australia, Melbourne, 1988.

For a general introduction to contemporary aesthetics, see B. Smith, European Vision in the South Pacific, London, 1960. For discussions of sexual imagery, use Roy Porter's 'Mixed Feelings: the Enlightenment and Sexuality in Eighteenth Century Britain', in P. Bouce (ed.), Sexuality in Eighteenth Century Britain, Manchester, 1982. For an Aboriginal woman's depiction of the ongoing tensions of black-white sexual relations, view the short film by Tracey Moffat, Nice Coloured Girls and discussion by K. Jennings and D. Hollinsworth, 'Ways of Seeing and Speaking About Aboriginal Women', in Hecate, vol. 13, no. 2, 1987-88. 